\title{
Twenty patients including 7 probands with autosomal dominant cutis laxa confirm clinical and molecular homogeneity
}

Smail Hadj-Rabia ${ }^{1 *+}$, Bert L Callewaert ${ }^{2^{*}}$, Emmanuelle Bourrat ${ }^{3}$, Marlies Kempers ${ }^{4}$, Astrid S Plomp ${ }^{5}$, Valerie Layet ${ }^{6}$, Deborah Bartholdi', Marjolijn Renard ${ }^{2}$, Julie De Backer ${ }^{2}$, Fransiska Malfait ${ }^{2}$, Olivier M Vanakker ${ }^{2}$, Paul J Coucke ${ }^{2}$, Anne M De Paepe ${ }^{2}$ and Christine Bodemer ${ }^{1 \dagger}$

\begin{abstract}
Background: Elastin gene mutations have been associated with a variety of phenotypes. Autosomal dominant cutis laxa $(A D C L)$ is a rare disorder that presents with lax skin, typical facial characteristics, inguinal hernias, aortic root dilatation and pulmonary emphysema. In most patients, frameshift mutations are found in the $3^{\prime}$ region of the elastin gene (exons 30-34) which result in a C-terminally extended protein, though exceptions have been reported.

Methods: We clinically and molecularly characterized the thus far largest cohort of ADCL patients, consisting of 19 patients from six families and one sporadic patient.

Results: Molecular analysis showed C-terminal frameshift mutations in exon 30, 32, and 34 of the elastin gene and identified a mutational hotspot in exon 32 (c.2262delA). This cohort confirms the previously reported clinical constellation of skin laxity (100\%), inguinal hernias (51\%), aortic root dilatation (55\%) and emphysema (37\%).

Conclusion: ADCL is a clinically and molecularly homogeneous disorder, but intra- and interfamilial variability in the severity of organ involvement needs to be taken into account. Regular cardiovascular and pulmonary evaluations are imperative in the clinical follow-up of these patients.
\end{abstract}

Keywords: Elastin, ELN, Autosomal dominant cutis laxa, Genotype, Phenotype

\section{Background}

Elastin gene $(E L N)$ mutations have been associated with various skin, cardiovascular and pulmonary phenotypes. Microdeletions of the region on 7q11, encompassing the ELN gene, result in Williams-Beuren syndrome (WBS, OMIM \#194050) [1]. This recognizable entity combines mental retardation with a happy demeanor, typical facial gestalt, a soft, slightly elastic and doughy skin, hypercalcaemia, and arterial stenoses, mainly of the supravalvular aorta. A related disorder is the supravalvular aortic stenosis (SVAS, OMIM \#185500) phenotype. These patients present without the mental and dysmorphic

\footnotetext{
* Correspondence: smail.hadj@inserm.fr; Bert.Callewaert@Ugent.be ${ }^{\dagger}$ Equal contributors

${ }^{1}$ Service de Dermatologie - Centre de référence national des Maladies Génétiques à Expression Cutanée (MAGEC), INSERM U781, Hôpital Necker Enfants Malades, Université Paris V-Descartes, 149, rue de Sèvres 75743 Paris Cedex 15, Paris, France

Full list of author information is available at the end of the article
}

features encountered in the WBS, but do show arterial stenoses. SVAS is caused by missense and premature truncation mutations that are dispersed throughout the ELN gene [2].

In contrast, frameshift mutations at the 3' terminus that result in a C-terminally elongated and secreted elastin protein [3-8] have been identified in autosomal dominant cutis laxa (ADCL, OMIM \#123700). This disorder comprises generalized skin redundancy, pulmonary emphysema and aortic root dilatation (ARD).

Different mechanisms underlying the perturbations subsequent to elastin mutations have been identified. In general, reduced elastin secretion and deposition, resulting in increased vascular smooth muscle cell proliferation and a higher number of smaller elastic lamellae, induces a phenotype dominated by arterial stenoses [9], while aberrant elastin protein production infers to elastic fiber

\section{Biomed Central}

(c) 2013 Hadj-Rabia et al.; licensee BioMed Central Ltd. This is an Open Access article distributed under the terms of the Creative Commons Attribution License (http://creativecommons.org/licenses/by/2.0), which permits unrestricted use, distribution, and reproduction in any medium, provided the original work is properly cited. 
fragmentation with manifest cutis laxa, arterial dilatation and/or emphysema [3].

To date, frameshift mutations in the 3'UTR of the elastin gene have been identified in 11 probands with ADCL, but it remains a matter of debate whether other molecular mechanisms could be involved. Indeed, two reports indicated a different molecular basis including a heterozygous mutation in exon 25 of the elastin gene [10], and a tandem duplication in the fibulin-5 gene [11], respectively. Moreover, in the absence of large patient cohorts, the ADCL phenotype is still insufficiently characterized and not always easy to discern from related forms of cutis laxa. Furthermore, the identification of an ELN variant in exon 34 (c.2318G>A; p. (G773D)) complicated genotype-phenotype correlations in the ELN gene. This variant was associated with pulmonary emphysema [12] and, in conjunction with a p. G202R alteration in the fibulin-5 protein, with acquired cutis laxa following a parasitic infection [13]. Finally, a case report mentions causal involvement of the ELN gene in a recessive form of cutis laxa due to a p.(P211S) alteration [14].

We report on six novel ADCL families, comprising 19 patients, and one sporadic patient, with a review of the literature. Our data favor homogeneity both at the clinical and molecular level.

\section{Methods}

\section{Clinical data}

Patients were evaluated by an experienced clinical geneticist or dermatologist. Written informed consent was obtained from each patient and family member before sample collection. Specific consents were obtained for publication of the clinical pictures. This study was approved by the medical ethical committee of Inserm (France) and of the Ghent University Hospital and the Declaration of Helsinki Principles were respected.

\section{Mutation screening}

Genomic DNA was extracted from peripheral blood leukocytes at Genethon's DNA Bank using standard procedures, followed by touchdown PCR amplification and sequencing of exons 28 through 34 of the $E L N$ gene as previously described [3]. Sequences were compared to the wild-type sequence as submitted to Ensembl Accession number ENST00000358929. Nucleotides were numbered starting from the first base of the initiation codon (ATG) of the cDNA reference sequence. Amino acid residues are numbered from the first methionine residue of the reference sequence. Segregation was verified in all families and mutations were absent in a panel of 100 Caucasian controls.

\section{Results}

\section{Clinical data}

We present six families and one sporadic patient (S1:II2) with ADCL. Pedigrees of the families are presented in Figure 1. Family 1 originates from the Netherlands, Family F2 from Switzerland, and all others from France. Twenty of the 27 patients were available for clinical evaluation (Table 1). Male to female ratio was 15/12. Curiously, in 20 out of 22 meioses the phenotype was inherited $\left(X^{2}=8.84 ; \mathrm{p}\right.$-value $\left.=0.003\right)$. Ages at last clinical evaluation ranged from 1 to 84 years, with 11 patients being over 21 years old.

All patients had areas of cutis laxa. A minority of patients (25\%) showed skin redundancy only in the facial, neck, inguinal and/or axillary regions, while $75 \%$ of patients had extensive to generalized cutis laxa. The facial skin showed a spectrum ranging from a coarse face over an aged appearance to overt cutis laxa. Especially the lower half of the face and neck region were involved with sagging cheeks, a flabby skin around the chin and skin redundancy in the neck region. Blepharochalasis and ptosis of the upper eyelid were often present (Figure 2J). The skin of the limbs was relatively spared. Overall, the skin had a soft feeling to the touch with variable hyperextensibility (Figure 2L). Skin abnormalities tended to improve with age but were highly variable between and within families. Surgery both for aesthetic reasons [sagging breasts (F1:II-2, F1:III-1) or lax abdominal skin (F2:I-1 and F2:II-1)] and for functional reasons [ptosis (F1:II-2)] was disappointing with frequent relapse. Wound healing was reported normal, although F1: III-1 mentioned recurrent superficial erosions, wound infections and nail fragility.

Craniofacial dysmorphism was mild but recognizable and showed a long face, large pliant ears, and a long philtrum (Figure 2). A beaked nose was present in most patients $(70 \%)$.

Inguinal hernias were frequent, appearing congenitally (F1:II-2, F1:II-3, F1:III-1, F2:II-1) or throughout life (F1: I- 2 at age 80 and F1:III- 4 at 18 years old) and often reoccurred after surgery (patient F1:II-2, F1:II-3, F1:II-3, F1:III-1). Patient F1:II-4 also had an umbilical hernia. Systemic involvement was noted in 15 out of 20 patients (75\%). Chronic obstructive pulmonary disease was diagnosed in eight patients, seven of whom had emphysema and one had asthma. F1:II-2 and F1:II-1 were significant smokers and the latter died at age 55 due to end-stage respiratory failure with emphysematous lung changes. Vascular involvement included ARD in eight patients, and a dilatation of the aortic arch in one (patient F4:II-2). In addition, patient F3:II-2 had pulmonary artery dilatation and patient F6:II-1 had a global but stable increase of the diameters of the arteries, especially of the carotid arteries (diameter increase of 30\%). Four 


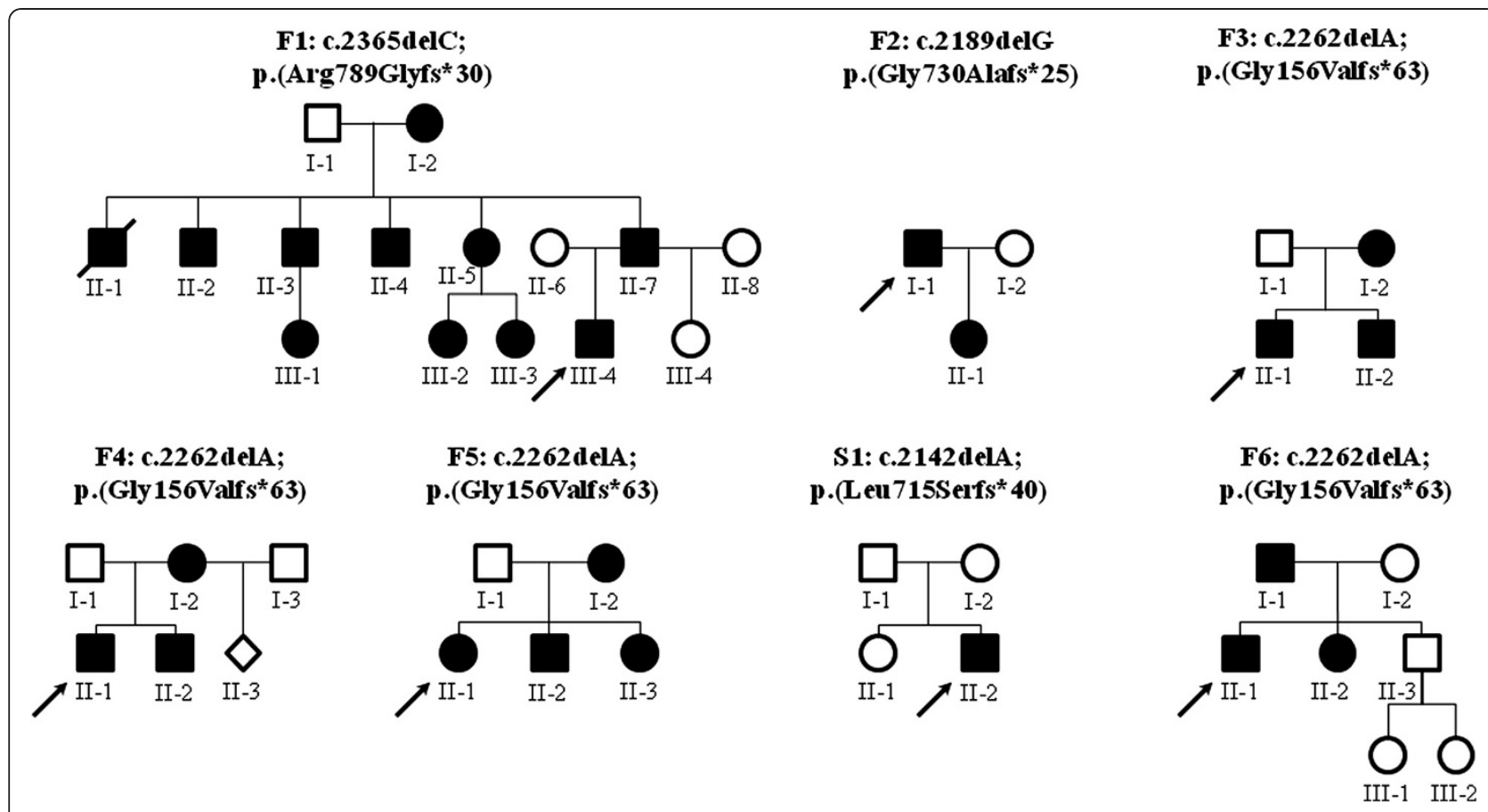

Figure 1 Pedigrees of the families described in this study. Round symbol, female; square, male; filled symbol, affected; open symbol, normal; slash line, deceased.

patients had aortic valve regurgitation (F1:II-4; F5:II-2, F5:II-3, F6:II-1), patient F1:II-3 had tricuspid valve stenosis, and patients F1:II-4 and F6-20 had mitral valve regurgitation. Other manifestations included gastrooesophageal reflux (F1:II-7 and F1:III-4), urogenital prolapse (F1:II-2), and a hoarse voice (F2:I-1, F2:II-1, F3: II-1, and F3:II-2).

Hypomobility of spermatozoids required in vitro fertilization for one patient (F1:II-3). None of the patients reported ocular problems. Growth and psychomotor development were appropriate in all patients.

\section{Genetic analysis}

The ELN mutations identified in these families are reported in Table 2 and Figure 1. We found three novel mutations: p.2189delG; p.(Gly730Alafs"25) and c.2142delG; p.(Leu715Serfs*40) in exon 30; and c.2365delC; p.(Arg789 Glyfs*30) in exon 34. One previously reported mutation (c.2262delA (p.Gly156Valfs"63)) in exon 32 was found in four families and may represent a mutational hotspot. All mutations are predicted to result in a C-terminal missense sequence with a read-through in the 3' UTR. Although exon 30 mutations induce a premature truncation in exon 32, (partial) splicing of this exon will result in a Cterminally elongated missense protein as previously reported for similar mutations $[3,5]$.

\section{Genotype-phenotype correlation}

There are no obvious genotype-phenotype correlations when comparing patients with mutations in different exons (Table 3). The recurrent c.2262delA mutation shows large interfamilial variability. Moreover, family 1 , 3 and 5 also document high intrafamilial variability, both in skin features and internal organ involvement.

Although the risk for ARD was suggested to be smaller in patients with exon 32 mutations [3], we did identify vascular involvement in this patient subgroup. However, ARD seems more prominent in association with exon 30 mutations (Table 3), but further confirmation is needed.

\section{Discussion}

We present the largest patient cohort with ADCL thus far. The phenotype is homogeneous and comprises generalized skin involvement, inguinal and umbilical hernias, ARD and emphysema. The disorder shows full penetrance, but with variable expression. The aspect and topography of the skin lesions is highly variable but the skin changes are most pronounced on the axillar, inguinal, neck and lower facial regions. In congruence with earlier reports $[5,8]$, skin manifestations improve with aging and the phenotype may be unrecognized in older patients. Although ADCL is often considered 'benign', systemic involvement, although variable, is frequently present. Both lung (present in 35\% of patients) and aortic involvement (present in $57 \%$ of patients) have led to premature death [5,7]. Patient management therefore warrants close monitoring of pulmonary function and aortic root diameters. No current treatment guidelines are available for ADCL patients. Because earlier reports 
Table 1 Clinical details of the patients available for clinical evaluation

\begin{tabular}{|c|c|c|c|c|c|c|c|c|c|c|c|c|}
\hline \multirow{3}{*}{ Patient } & \multirow{3}{*}{$\begin{array}{c}\text { Sex, } \\
\text { Age }(y)\end{array}$} & \multicolumn{7}{|c|}{ Skin } & \multirow{3}{*}{$\begin{array}{l}\text { Inguinal } \\
\text { hernia } \\
\text { Left (L)/Right } \\
\text { (R)/Bilateral } \\
\text { (B) (times } \\
\text { surgery) }\end{array}$} & \multirow[t]{3}{*}{ Cardiovascular } & \multirow{3}{*}{$\begin{array}{l}\text { Pulmonary } \\
\text { emphysema }\end{array}$} & \multirow[t]{3}{*}{ Other } \\
\hline & & \multirow[t]{2}{*}{ Aspect } & \multicolumn{6}{|c|}{ Topography } & & & & \\
\hline & & & Trunk & $\begin{array}{l}\text { Axillar } \\
\text { region }\end{array}$ & $\begin{array}{l}\text { Inguina } \\
\text { region }\end{array}$ & Limbs & Neck & Face & & & & \\
\hline F1:1-1 & $F, 84$ & Redundant & + & + & + & & & & $L(1)$ & - & + & $\begin{array}{c}\text { Bilateral ptosis, sagging breasts, } \\
\text { pelvic prolapse }\end{array}$ \\
\hline F1:II-2 & $M, 59$ & Smooth, sagging, loose & & + & + & & + & + & B (10). & - & + & Pliant ears \\
\hline F1:II-3 & $M, 57$ & $\begin{array}{l}\text { Smooth, redundant } \\
\text { sagging }\end{array}$ & + & + & & & & + & $B(12)$ & TVS ARD & + & Nycturia, decreased fertility \\
\hline \multirow[t]{2}{*}{ F1:II-4 } & \multirow[t]{2}{*}{$M, 53$} & \multirow{2}{*}{$\begin{array}{l}\text { Sagging loose, sagging, } \\
\text { redundant }\end{array}$} & & \multirow[t]{2}{*}{+} & \multirow[t]{2}{*}{+} & \multirow[t]{2}{*}{+} & \multirow[t]{2}{*}{+} & \multirow[t]{2}{*}{+} & \multirow[t]{2}{*}{$B(15)$} & \multirow{2}{*}{$\begin{array}{c}\text { ARD (85mm - surgery), } \\
\text { AR, MR }\end{array}$} & \multirow[t]{2}{*}{+} & Umbilical hernia \\
\hline & & & & & & & & & & & & $\begin{array}{l}\text { Inguinal hernia surgery (13 } \\
\text { times) }\end{array}$ \\
\hline F1:II-5 & $F, 51$ & $\begin{array}{l}\text { Sagging loose, sagging, } \\
\text { redundant }\end{array}$ & + & + & + & & + & + & - & - & - & \\
\hline F1:II-7 & $M, 46$ & Loose, sagging & + & & & & + & + & - & - & - & $\begin{array}{c}\text { Gastroesophageal reflux disease } \\
\text { strabismus }\end{array}$ \\
\hline$F 1:|| \mid-1$ & $F, 23$ & $\begin{array}{l}\text { Sagging, loose, } \\
\text { redundant }\end{array}$ & + & + & + & & + & & $B(2)$ & - & - & Sagging breasts \\
\hline$F 1:|| l-4$ & $M, 22$ & Sagging & + & & & & & + & $\mathrm{R}(2)$ & ARD & - & $\begin{array}{l}\text { Gastroesophageal reflux disease } \\
\text { coarse face }\end{array}$ \\
\hline$F 2: 1-1$ & $M, 48$ & Redundant & & + & + & & & & - & - & + & $\begin{array}{c}\text { Hoarse voice, corrective skin } \\
\text { surgery }\end{array}$ \\
\hline$F 2: \|-1$ & $F, 21$ & Redundant & & + & + & & & & $\mathrm{B}(0)$ & MVP & + & $\begin{array}{l}\text { Hoarse voice, corrective skin } \\
\text { surgery ( } 3 \text { times) }\end{array}$ \\
\hline$F 3: 1-2$ & $F, 31$ & Excessive, sagging & + & + & + & + & + & + & - & ARD & - & \\
\hline F3:II-1 & $M, 7$ & Excessive, sagging & & & & & + & + & - & ARD & - & Hoarse voice \\
\hline$F 3: I-2$ & $M, 4$ & Excessive, sagging & + & + & + & + & + & + & - & Pulmonary artery dilatation & Asthma & Atopic dermatitis, hoarse voice \\
\hline F4:II-1 & $M, 16$ & Redundant & + & + & + & & & + & - & ARD & & Coarse face \\
\hline F4:II-2 & $M, 14$ & - & & & & & & + & - & Dilated aortic arch $(27 \mathrm{~mm})$ & & Coarse face \\
\hline $\mathrm{F} 5: I-1$ & $F, 14$ & Excessive, sagging & + & + & + & + & + & + & - & - & - & Labiae major coalescence \\
\hline $\mathrm{F} 5: I-2$ & $\mathrm{M}, 10$ & Excessive, sagging & + & + & + & + & + & + & - & AR & - & Testis ectopia \\
\hline$F 5: \| 1-3$ & $F, 7$ & Excessive, sagging & + & + & + & + & + & + & - & $\begin{array}{l}\text { AR, Borderline ARD } \\
(23 \mathrm{~mm})\end{array}$ & - & \\
\hline S1:II-2 & $M, 1$ & Excessive, sagging, & + & + & + & & & + & - & ARD & & \\
\hline F6:II-1 & M, 39 & Redundant & + & + & & & & + & - & $\begin{array}{l}\text { AR, global increase of } \\
\text { arterial diameter }\end{array}$ & - & \\
\hline
\end{tabular}



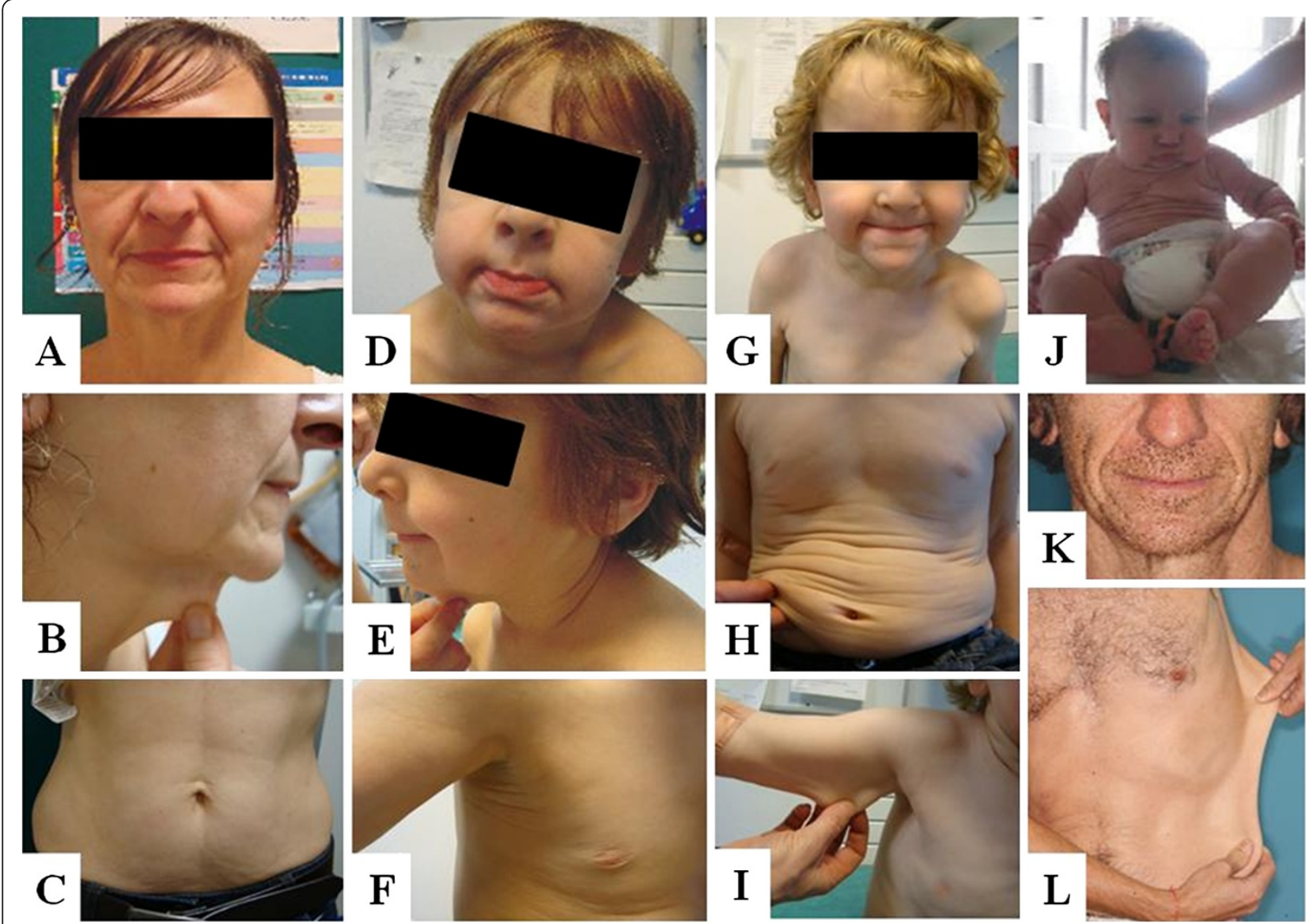

Figure $\mathbf{2}$ Clinical aspects of affected patients. Facial characteristics include large ears, a long, coarse face, blepharochalasis, ptosis, a beaked nose and a large philtrum. Note the variability of skin phenotype at different ages. (A-C) Typical facial characteristics, slightly hyperextensible skin, mild rimpling and sagging of the abdominal skin in patient F3:I-2. (D-F) Typical facial characteristics, slightly hyperextensible skin, and small redundant skin folds of the axillar folds in patient F3:I-1. (G-I) Typical facial characteristics, manifest loose, redundant and sagging skin folds of the abdominal skin and slightly hyperextensible skin of the limbs in patient F3:II-2. (J) Patient S1:I-2 at the age of 1 year presenting with typical facial characteristics and generalized, loose, redundant skin folds. (K-L) Facial characteristics and skin hyperextensibility in patient F6:II-1.

indicated increased TGF $\beta$ signaling in the pathogenesis [3], thresholds for aortic surgery could be based on similar parameters as in elastinopathies/TGF $\beta$ signalopathies associated with ARD (actual aortic diameter, rate of aortic growth, family history, the patient's estimation of the risk, and pregnancy wish) [15]. Moreover, this mechanism might reveal a role for treatment with losartan, an

Table 2 ELN mutations identified in this cohort

\begin{tabular}{llll}
\hline Patients & Origin & cDNA level & Protein level \\
\hline Family 1 & Netherlands & c.2365delC (exon 34) & p.(Arg789GlyfsX30) \\
Family 2 & Switzerland & c.2189delG (exon 30) & p.(Gly730AlafsX25) \\
Family 3 & France & c.2262delA (exon32) & p.(Gly156ValfsX63) \\
Family 4 & France & c.2262delA (exon32) & p.(Gly156ValfsX63) \\
Family 5 & France & c.2262delA (exon32) & p.(Gly156ValfsX63) \\
Sporadic case & France & c.2142delG (exon 30) & p.(Leu715SerfsX40) \\
Family 6 & France & c.2262delA (exon32) & p.(Gly156ValfsX63) \\
\hline
\end{tabular}

angiotensin II type 1 receptor blocker with TGF $\beta$ antagonistic effect. Surgery for skin manifestations and hernias is disappointing and should be discouraged if done purely for aesthetic reasons.

The phenotype can be distinguished from autosomal recessive types of cutis laxa (ARCL) based on facial gestalt, the absence of skeletal, ocular, and central nervous involvement (type 2 and 3 ARCL) [16,17], and the absence of severe early onset emphysema and gastrointestinal and genitourinary diverticula (type 1a/c ARCL [18]) or arterial involvement (type $1 \mathrm{~b}$ related cutis laxa) [19] (Table 4). The small number of patients described to date does not allow drawing straight-forward genotypephenotype correlations, although a tendency for a milder vascular phenotype exists in exon 32 mutations. Mutations in this exon might be partially rescued by enhanced splicing of this exon [3].

The clinical homogeneity of the phenotype corresponds to a striking molecular homogeneity with mutations found 
Table 3 Genotype - phenotype correlations in ADCL

\begin{tabular}{lcccccccccc}
\hline Missense & F/M individuals & Mean age & FH & IH & FG & ARD & BAV & VA & Emphys & transmission \\
\hline Exon 30 & $5 / 7$ & 21.9 & 50 & 64 & 100 & 82 & 10 & 70 & 40 & 100 \\
Exon 32 & $6 / 6$ & 17.1 & 90 & 17 & 100 & 50 & 0 & 25 & 0 & 95 \\
Exon 33 & $2 / 2$ & 21 & 33 & 50 & 100 & 50 & 25 & 50 & 100 & 100 \\
Exon 34 & $3 / 5$ & 49.5 & 100 & 75 & 100 & 38 & 0 & 25 & 50 & 91 \\
Chr rearr & $3 / 0$ & 42 & 100 & 67 & 100 & $?$ & 0 & 0 & 100 & 56 \\
Total & $19 / 20$ & 27.3 & 63 & 50 & 100 & 57 & 5 & 38 & 35 & 83 \\
\hline
\end{tabular}

Frequencies (\%) of the clinical characteristics are given for mutations in the different exons. Chr rear, Chromosomal rearrangement as described by [7]. Mean age in years. $F$, female; $M$, male; $F H$, family history; $I H$, Inguinal hernia; $F G$, Facial gestalt; $A R D$, aortic root dilatation; $B A V$, bicuspid aortic valve; $V A$, other valve anomalies; Emphys, emphysema. References: [3-8].

in the 3'terminus of the ELN gene. All mutations reside in exons $30,32,33$, and 34 and result in a missense and elongated sequence at the $\mathrm{C}$-terminus of the elastin protein [3-8]. Mutation analysis should focus firstly on these exons, although splice site mutations elsewhere in the $E L N$ gene could also result in a C-terminal extension of the protein. Frameshift mutations resulting in $\mathrm{C}$ terminal protein extensions have been identified in a variety of other diseases resulting in mislocalization, altered secretion, increased or decreased stability, resistance to proteases, loss-of-function, gain-of-function, and novel functions of the affected protein [23-28]. Extended proteins may also result from impaired processing of propeptides. A well-known example within the field of connective tissue disorders is the EhlersDanlos syndrome type VII that results from mutations in the substrate collagen type 1 or in its type 1 procollagen N-proteinase (type VIIC). In both cases the $\mathrm{N}$-terminus of the procollagen type 1 is not removed and the mutant collagen is deposited into the extracellular matrix with severe dermal and internal organ consequences $[29,30]$. In ADCL it was shown that the altered and extended C-terminus resulted in increased endoplasmatic reticulum stress (due to protein misfolding), increased coacervation and elastin globule formation leading to lower amounts of insoluble, mature elastin. Enhanced TGF $\beta$ signaling is probably secondary to altered elastic fiber anatomy [3].

Two reports indicated molecular heterogeneity in ADCL. In a single ADCL patient, a tandem duplication in the FBLN5 gene was shown to result in secretion of mutant protein, suggesting a dominant negative effect [11]. However, mutant protein integration in the extracellular matrix has been shown in FBLN5 related ARCL type 1 [31] and carriers of these mutations do not have a cutis laxa phenotype. A second report showed a mutation in exon 25 of the ELN gene which encodes a conserved cross-linking domain important for insoluble elastin formation [10]. This patient also presented with severe neurological involvement, which was not attributed to his cutis laxa syndrome. His father carried the same alteration, but did not exhibit any phenotype. Future confirmation of these two defects may shed further insights on the molecular heterogeneity of ADCL. Until then, ADCL can be considered as a phenotypically and genetically homogeneous disorder in which analysis

Table 4 Clinical characteristics of ADCL and type 1 recessive cutis laxa syndromes

\begin{tabular}{|c|c|c|c|c|}
\hline & $\begin{array}{l}\mathrm{ADCL} \\
(E L N)\end{array}$ & $\begin{array}{l}\text { ARCL type la } \\
\text { (FBLN5) }\end{array}$ & $\begin{array}{c}\text { ARCL type } 1 \mathrm{c} \\
\text { (LTBP4) }\end{array}$ & $\begin{array}{c}\text { ARCL type } 1 \mathrm{~b} \\
(\text { FBLN4) }\end{array}$ \\
\hline Dysmorphism & $\begin{array}{l}\text { Long philtrum, } \\
\text { beaked nose }\end{array}$ & $\begin{array}{l}\text { Long philtrum, large ears, } \\
\text { beaked nose }\end{array}$ & $\begin{array}{c}\text { Long philtrum, large ears, beaked nose, sparse } \\
\text { hair on temporal sides }\end{array}$ & \\
\hline \multirow[t]{2}{*}{ Skin } & $\begin{array}{l}\text { Loose redundant } \\
\text { skin folds }\end{array}$ & $\begin{array}{l}\text { Loose redundant skin } \\
\text { folds }\end{array}$ & Loose redundant skin folds & Hyperextensible skin \\
\hline & Coarse face & & & Skin redundancy \\
\hline Cardiovascular & $\begin{array}{l}\text { ARD, valvular } \\
\text { anomalies }\end{array}$ & SVAS, PPAS & PPAS, CPAS & $\begin{array}{l}\text { ARD, multiple arterial } \\
\text { aneurysms }\end{array}$ \\
\hline Emphysema & + & +++ & +++ & $+/-$ \\
\hline Genitourinary diverticula & + & +++ & ++ & $?$ \\
\hline $\begin{array}{l}\text { Gastro-intestinal } \\
\text { diverticula/tortuosity }\end{array}$ & - & + & +++ & $?$ \\
\hline Inheritance & $A D$ & $A R$ & $A R$ & $A R$ \\
\hline
\end{tabular}

$A R D$, aortic root dilatation; SVAS, supravalvular aortic root stenosis; PPAS, peripheral pulmonary artery stenosis; $C P A S$, common pulmonary artery stenosis; $A D$, autosomal dominant; $A R$, autosomal recessive. References: [3-8,18-22]. 
of exon 30-34 of the ELN gene is indicated in first instance.

\section{Conclusion}

This cohort of patients further indicates that ADCL is a systemic disorder with a risk for major complications including aortic root dilatation and pulmonary emphysema, warranting regular follow-up. The molecular data favor a single mutational mechanism resulting in a stable C-terminal extension of the elastin protein.

\section{Abbreviations}

ADCL: Autosomal dominant Cutis Laxa; ARCL: Autosomal recessive cutis laxa; ARD: Aortic rooth dilatation; ELN: Elastin; SVAS: Supravalvular aortic stenosis; WBS: Williams-Beuren syndrome; TGF $\beta$ : Transforming Growth Factor $\beta$.

\section{Competing interests}

The authors declare no competing interests.

\section{Authors' contributions}

SHR and BLC reviewed patients, designed the study and drafted the manuscript. EB, MK, ASP, VL and DB reviewed patients. MR and PJC performed and supervised the molecular analyses. JDB, FM, OMV and ADP contributed to clinical assessment, sample collection and drafting of the manuscript. CB reviewed patients, and contributed in the design of the study. All authors have read and approved the final manuscript.

\section{Acknowledgements}

This work was supported by a Methusalem grant to ADP (BOF 08/01M01108 from the Ghent University and Flemish Government) providing funding to perform the molecular analysis. JDB is a senior clinical investigator and BC and FM are postdoctoral research fellows of the Fund for Scientific Research - Flanders. OV has a BOF research fellowship from the Ghent University. We are indebted to the families involved in this study as well as to REEL (Réseau élastique), a French collaboration network on inherited diseases of the elastic fibers, that supports research by providing logistic support in patient assembly, evaluation and sample gathering and that supports patients in daily life. Besides SHR, BLC, ADP and CB, the network further consists of Romain Debret (romain.debret@ibcp.fr), Pascal Sommer (p.sommer@ibcp.fr), Safa Saker (saker@genethon.fr), Alice Phan (alice.phan@chu-lyon.fr), Ludovic Martin (LuMartin@chu-angers.fr),Frédéric Caux (frederic.caux@avc.aphp.fr) and Marie-Claude Boiteux (mcjlboiteux@aol.com).

\section{Author details}

${ }^{1}$ Service de Dermatologie - Centre de référence national des Maladies Génétiques à Expression Cutanée (MAGEC), INSERM U781, Hôpital Necker Enfants Malades, Université Paris V-Descartes, 149, rue de Sèvres 75743 Paris Cedex 15, Paris, France. ${ }^{2}$ Center for Medical Genetics, Ghent University Hospital, De Pintelaan 185, B-9000, Ghent, Belgium. ${ }^{3}$ Service de Dermatologie, MAGEC Hôpital Saint-Louis, Paris, France. ${ }^{4}$ University Medical Center St. Radboud, Nijmegen, the Netherlands. ${ }^{5}$ Academic Medical Center, Amsterdam, the Netherlands. ${ }^{6}$ Groupe Hospitalier Du Havre - Department of Medical Genetics, Le Havre, France. ${ }^{7}$ Institute of Medical Genetics, University of Zürich, Zürich, Switzerland.

Received: 27 November 2012 Accepted: 14 February 2013 Published: 25 February 2013

\section{References}

1. Ewart AK, Morris CA, Atkinson D, Jin W, Sternes K, Spallone P, Stock AD, Leppert M, Keating MT: Hemizygosity at the elastin locus in a developmental disorder, Williams syndrome. Nat Genet 1993, 5:11-16.

2. Curran ME, Atkinson DL, Ewart AK, Morris CA, Leppert MF, Keating MT: The elastin gene is disrupted by a translocation associated with supravalvular aortic stenosis. Cell 1993, 73:159-168.

3. Callewaert B, Renard M, Hucthagowder V, Albrecht B, Hausser I, Blair E, Dias C, Albino A, Wachi H, Sato F, et al: New insights into the pathogenesis of autosomal-dominant cutis laxa with report of five ELN mutations Hum Mutat 2011, 32:445-455.

4. Rodriguez-Revenga L, Iranzo P, Badenas C, Puig S, Carrio A, Mila M: A nove elastin gene mutation resulting in an autosomal dominant form of cutis laxa. Arch Dermatol 2004, 140:1135-1139.

5. Szabo Z, Crepeau MW, Mitchell AL, Stephan MJ, Puntel RA, Yin Loke K, Kirk $R C$, Urban Z: Aortic aneurysmal disease and cutis laxa caused by defects in the elastin gene. J Med Genet 2006, 43:255-258.

6. Tassabehji M, Metcalfe K, Hurst J, Ashcroft GS, Kielty C, Wilmot C, Donnai D, Read AP, Jones $\mathrm{CJ}$ : An elastin gene mutation producing abnormal tropoelastin and abnormal elastic fibres in a patient with autosomal dominant cutis laxa. Hum Mol Genet 1998, 7:1021-1028.

7. Urban Z, Gao J, Pope FM, Davis EC: Autosomal dominant cutis laxa with severe lung disease: synthesis and matrix deposition of mutant tropoelastin. J Invest Dermatol 2005, 124:1193-1199.

8. Zhang MC, He L, Giro M, Yong SL, Tiller GE, Davidson JM: Cutis laxa arising from frameshift mutations in exon 30 of the elastin gene (ELN). J Biol Chem 1999, 274:981-986.

9. Pober BR, Johnson M, Urban Z: Mechanisms and treatment of cardiovascular disease in Williams-Beuren syndrome. J Clin Invest 2008, 118:1606-1615

10. Graul-Neumann LM, Hausser I, Essayie M, Rauch A, Kraus C: Highly variable cutis laxa resulting from a dominant splicing mutation of the elastin gene. Am J Med Genet A 2008, 146A:977-983.

11. Markova D, Zou Y, Ringpfeil F, Sasaki T, Kostka G, Timpl R, Uitto J, Chu ML: Genetic heterogeneity of cutis laxa: a heterozygous tandem duplication within the fibulin-5 (FBLN5) gene. Am J Hum Genet 2003, 72:998-1004.

12. Kelleher CM, Silverman EK, Broekelmann T, Litonjua AA, Hernandez M, Sylvia JS, Stoler J, Reilly JJ, Chapman HA, Speizer FE, et al: A functional mutation in the terminal exon of elastin in severe, early-onset chronic obstructive pulmonary disease. Am J Respir Cell Mol Biol 2005, 33:355-362.

13. Hu Q, Reymond JL, Pinel N, Zabot MT, Urban Z: Inflammatory destruction of elastic fibers in acquired cutis laxa is associated with missense alleles in the elastin and fibulin-5 genes. J Invest Dermatol 2006, 126:283-290.

14. Megarbane H, Florence J, Oliver Sass J, Schwonbeck S, Foglio M, de Cid R, Cure S, Saker S, Megarbane A, Fischer J: An autosomal-recessive form of cutis laxa is due to homozygous elastin mutations, and the phenotype may be modified by a heterozygous fibulin 5 polymorphism. J Invest Dermatol 2009, 129:1650-1655.

15. Loeys BL, Dietz HC, Braverman AC, Callewaert BL, De Backer J, Devereux RB, Hilhorst-Hofstee Y, Jondeau G, Faivre L, Milewicz DM, et al: The revised Ghent nosology for the Marfan syndrome. J Med Genet 2010, 47:476-485.

16. Kornak U, Reynders E, Dimopoulou A, van Reeuwijk J, Fischer B, Rajab A, Budde B, Nurnberg P, Foulquier F, Lefeber D, et al: Impaired glycosylation and cutis laxa caused by mutations in the vesicular $\mathrm{H}+$-ATPase subunit ATP6V0A2. Nat Genet 2008, 40:32-34

17. Reversade B, Escande-Beillard N, Dimopoulou A, Fischer B, Chng SC, Li Y, Shboul M, Tham PY, Kayserili H, Al-Gazali L, et al: Mutations in PYCR1 cause cutis laxa with progeroid features. Nat Genet 2009, 41:1016-1021.

18. Callewaert B, Su CT, Van Damme T, Vlummens P, Malfait F, Vanakker $O$, Schulz B, Mac Neal M, Davis EC, Lee JG, et al: Comprehensive clinical and molecular analysis of 12 families with type 1 recessive cutis laxa. Hum Mutat 2013, 34:111-121.

19. Renard M, Holm T, Veith R, Callewaert BL, Ades LC, Baspinar O, Pickart A, Dasouki M, Hoyer J, Rauch A, et al: Altered TGFbeta signaling and cardiovascular manifestations in patients with autosomal recessive cutis laxa type I caused by fibulin-4 deficiency. Eur J Hum Genet 2010, 18:895-901.

20. Hucthagowder V, Sausgruber N, Kim KH, Angle B, Marmorstein LY, Urban Z Fibulin-4: a novel gene for an autosomal recessive cutis laxa syndrome. Am J Hum Genet 2006, 78:1075-1080.

21. Loeys B, Van Maldergem L, Mortier G, Coucke P, Gerniers S, Naeyaert JM, De Paepe A: Homozygosity for a missense mutation in fibulin-5 (FBLN5) results in a severe form of cutis laxa. Hum Mol Genet 2002, 11:2113-2118,

22. Urban Z, Hucthagowder V, Schurmann N, Todorovic V, Zilberberg L, Choi J, Sens C, Brown CW, Clark RD, Holland KE, et al: Mutations in LTBP4 cause a syndrome of impaired pulmonary, gastrointestinal, genitourinary, musculoskeletal, and dermal development. Am J Hum Genet 2009, 85:593-605

23. Arlt G, Brooks DA, Isbrandt D, Hopwood JJ, Bielicki J, Bradford TM, BindlossPetherbridge CA, von Figura K, Peters C: Juvenile form of 
mucopolysaccharidosis VI (Maroteaux-Lamy syndrome). A C-terminal extension causes instability but increases catalytic efficiency of arylsulfatase B. J Biol Chem 1994, 269:9638-9643.

24. Choi BY, Kim DH, Chung T, Chang M, Kim EH, Kim AR, Seok J, Chang SO, Bok J, Kim D, et al: Destabilization and Mislocalization of POU3F4 by CTerminal Frameshift Truncation and Extension Mutation. Hum Mutat 2013, 34:309-316.

25. Dickey DM, Yoder AR, Potter LR: A familial mutation renders atrial natriuretic Peptide resistant to proteolytic degradation. J Biol Chem 2009, 284:19196-19202.

26. Komaru K, Ishida Y, Amaya Y, Goseki-Sone M, Orimo H, Oda K: Novel aggregate formation of a frame-shift mutant protein of tissuenonspecific alkaline phosphatase is ascribed to three cysteine residues in the C-terminal extension. Retarded secretion and proteasomal degradation. FEBS J 2005, 272:1704-1717.

27. Soldovieri MV, Castaldo P, lodice L, Miceli F, Barrese V, Bellini G, Miraglia del Giudice E, Pascotto A, Bonatti S, Annunziato L, Taglialatela M: Decreased subunit stability as a novel mechanism for potassium current impairment by a KCNQ2 C terminus mutation causing benign familial neonatal convulsions. J Biol Chem 2006, 281:418-428.

28. Bohm J, Heinritz W, Craig A, Vujic M, Ekman-Joelsson BM, Kohlhase J, Froster U: Functional analysis of the novel TBX5 C.1333delC mutation resulting in an extended TBX5 protein. BMC Med Genet 2008, 9:88.

29. Colige A, Sieron AL, Li SW, Schwarze U, Petty E, Wertelecki W, Wilcox W, Krakow D, Cohn DH, Reardon W, et al: Human Ehlers-Danlos syndrome type VII C and bovine dermatosparaxis are caused by mutations in the procollagen I N-proteinase gene. Am J Hum Genet 1999, 65:308-317.

30. Smith LT, Wertelecki W, Milstone LM, Petty EM, Seashore MR, Braverman IM, Jenkins TG, Byers PH: Human dermatosparaxis: a form of Ehlers-Danlos syndrome that results from failure to remove the amino-terminal propeptide of type I procollagen. Am J Hum Genet 1992, 51:235-244.

31. Hu Q, Loeys BL, Coucke PJ, De Paepe A, Mecham RP, Choi J, Davis EC, Urban Z: Fibulin-5 mutations: mechanisms of impaired elastic fiber formation in recessive cutis laxa. Hum Mol Genet 2006, 15:3379-3386.

doi:10.1186/1750-1172-8-36

Cite this article as: Hadj-Rabia et al: Twenty patients including 7

probands with autosomal dominant cutis laxa confirm clinical and molecular homogeneity. Orphanet Journal of Rare Diseases 2013 8:36.

\section{Submit your next manuscript to BioMed Central and take full advantage of:}

- Convenient online submission

- Thorough peer review

- No space constraints or color figure charges

- Immediate publication on acceptance

- Inclusion in PubMed, CAS, Scopus and Google Scholar

- Research which is freely available for redistribution 